\title{
BRICS cooperation for the Critical Agrarian Studies: Challenges for the international research network under the new global geopolitics
}

\section{P. Niederle}

Paulo Niederle, DSc (Social Sciences), Associate Professor, Federal University of Rio Grande do Sul (Porto Alegre, Brazil). E-mail: pauloniederle@gmail.com.ru

DOI: $10.22394 / 2500-1809-2019-4-1-164-170$

In December 2018, Brazil hosted the Sixth international conference of the BRICS Initiative for Critical Agrarian Studies (BICAS). The conference united about 200 researchers and students from BRICS (Brazil, Russia, India, China and South Africa) and non-BRICS countries, and these scholars with social movements' representatives mainly from the Brazilian Confederation of Family Farmers (Contag) and the Landless Movement (MST). Perhaps, due to the number and qualification of participants or due to the dialogue with social movements and organizations BICAS has become one of the most important international networks focusing on agrarian and agrifood studies.

For the first time since its establishment in 2013, the conference provided conditions for the dialogue of agrarian scientists with researchers not interested in agrarian issues but rather in the new international geopolitical context. This dialogue allowed to better understand the consequences of the contemporary autocratic and neoliberal policies on agriculture, food production and rural communities, and, at the same time, to reconsider how such governments take advantage of new forms of agro-extrativism to support their political and economic strategies. The article aims at presenting the key issues of this dialogue and at identifying the challenges for the research agenda that focuses on critical agrarian studies.

BICAS is a network of academic organizations and researchers studying the BRICS agrarian dynamics as connected with the global food regime reconfigurations. This project was established at the conference organized by the Land Deal Politics Initiative in 2011, at the Institute of Development Studies (UK) that is still a very active organization in promoting BICAS. As BRICS countries were changing under the massive investments of the corporate and financial capital, which have completely changed the agrifood system dynamics, the network of organizations decided to promote a conference in Beijing in 
2013 to unite researchers from all BRICS countries. This event can be considered the BICAS Initiative starting point followed by conferences in Brasilia (2014), Cape Town (2015), Beijing (2016), Moscow (2017), and then again in Brasília (2018). The next conference will be held in 2020 in India as the least integrated country in the network.

In the last six years, BICAS has become an amazing opportunity for scientific cooperation of the BRICS-based or connected scholars. Although the initiative is supported by BRICS-based organizations - the Russian Presidential Academy of National Economy and Public Administration (RANEPA), the Institute for Poverty, Land and Agrarian Studies (PLAAS) in South Africa, the College of Humanities and Development Studies in China (COHD), and the Universities of Brasília (UND), Rio Grande do Sul (UFRGS) and São Paulo (UNESP) in Brazil, the network is open to all researchers and organizations focusing on agrarian economies and food systems in the BRICS countries. For instance, the Institute of Social Studies (ISS) and the Transnational Institute (TNI) are two Dutch organizations very active in the network since the beginning, i.e. the BICAS has become an open global initiative in which the debates are not limited to the BRICS context but cover a larger puzzle of the contemporary global food regime.

The last BICAS conference focused on how the increasing financialization of the food system and the resurgent authoritarian populism have promoted profound changes in agrarian economies. These processes have induced new practices of capitalist accumulation in which old forms of extractivism are interconnected with contemporary technologies that allow the financial control over the entire agrifood chain - from input markets to retail. To explain these changes in the historical perspective, at the opening session, Henry Veltmeyer (Saint Mary's (Canada) and Zacatecas (Mexico) Universities) discussed "The political economy of agro-extraction: The agrarian question of the 21st century". His argument was very similar to David Harvey's last works on "accumulation by dispossession": under the contemporary crisis capitalism is increasingly engaged in creating new forms of "primitive" accumulation that, by means of neo-extractivism, threatens the reproduction of natural resources, rural and urban communities, and even the entire planet due to such global dynamics as the climate change. BRICS countries have become the heart of these practices.

The first plenary session discussed BRICS investments in Africa, Asia and Latin America to explain how BRICS cooperation is different from the North-South historically asymmetric economic relations. Eduardo Gomes (Fluminense Federal University (UFF), Brazil) started his lecture by questioning the very idea of BRICS as a politically and economically coherent coalition. Are these countries really acting as a bloc in the international arena? Do they have similar interests, strategies, discourses and practices? Do they create in-
167

P. Niederle

BRICS cooperation for the Critical

Agrarian Studies:

Challenges for

the international

research network under the new

global geopolitics 
168 novative mechanisms of cooperation? Perhaps, the only evident consensus here is the huge heterogeneity of the bloc mainly because China is a member whose Gross Domestic Product (GDP) is larger than of all others combined.

Ye Jingzhong (COHD, China) and Isabela Nogueira de Moraes (LabChina, Brazil) studied the features of the Chinese participation in BRICS considering both the global scenario and the domestic challenges the country faces. On the one hand, Moraes's analysis clearly demonstrated how China takes advantage of the block to intensify its economic investments to control strategic natural resources such as land, minerals reserves and agricultural products. On the other hand, Jingzhong explained this strategy by the Chinese domestic policies focusing on the industrial development and food security. What is astonishing in this debate is the contradiction of the Chinese rural development strategies: while the government takes huge efforts to boost the national "rural revitalization" by supporting ecological modernization of family farming, the foreign Chinese actions have been very predatory in terms of land and water due to the land grabbing contributing to severe social and environmental conflicts that affect family farmers and peasant communities not only in the BRICS countries but worldwide.

To a lesser extent, this conflict determines the Brazilian state's action. In fact, Brazil policies are even more contradictory considering the unsolved tensions due to the government's efforts to ensure the coexistence of family farmers and agribusiness corporations. In the last two decades, Brazil has made important advances in food security policies that are largely based on the state support for small family farmers. Some such policies have been exported to other countries, mainly to Africa, with the strong support of the Brazilian government and multilateral organizations such as the FAO. However, this same government has been even more generous to expand the export-oriented production, which threatens the reproduction of family farmers and, consequently, food security and sovereignty. Besides, as stressed by Lidia Cabral (IDS, UK), the Brazilian state supports investments of agribusiness corporations overseas (especially in Africa), which contribute to the global land grabbing and destroy local food systems.

The situation in India also proves the huge challenges the governments face in the agrarian sector. According to Sudhir Kumar Suthar (CPS, India), India lives in the huge agrarian crisis that in 2018 led to the farmers' huge demonstrations against the food markets deregulation. The financial pressure on India's farmers is determined, on the one hand, by the rise of agricultural inputs prices (mainly fuel and fertilizers), and, on the other hand, by the decline of food prices in domestic markets due to the increasing farmers' indebtedness. In part this situation is a result of public policies of agricultural modernization. Recently, productivity of several crops has reached the record levels in India, that is why imports from Canada, Austral- 
ia and Russia fell to the lowest level since 2000. India is also to beat Brazil as the world's leader in sugar production. However, this modernization has resulted in the drop of domestic prices, and farmers demand from the state to create alternatives. It is necessary to remember that peasants and agriculture workers represent about half of India's 1.3 billion population.

The state policies were in the focus of the second plenary session, at which Alexander Nikulin (RANEPA, Russia) described the Russian food policies, and his analysis was supplemented at the next session by his colleague Alexander Kurakin. As we all know, Russia has adopted protectionist policies concerning food supply, which in 2014 were defined as the "food embargo", a counter-sanction policy of the Russian government in response to the European and North-American sanctions. The Russian government takes efforts to modernize agriculture mainly by supporting agro-holdings and family farmers. Although this resembles the Brazilian case, there are at least two main differences. First, most Russian family farmers have productive structures similar rather to the Brazilian agribusiness than to small family farmers. Indeed, in Russia this group is very specialized and engaged in commodity production and export. Second, the Russian government investments support primarily national companies and agrarian oligarchies rather than the foreign capitals that found in Brazil a much friendlier institutional environment.

At this session, another topic attracted my attention (unfortunately, I have to be very selective in this résumé of debates leaving out some speakers and issues) - the pernicious relations between governments and the corporate capital as the core of the agro-extractivist mode of accumulation. George Mészáros' (Warwick University, UK) analyzed the connection between the economic and ecological dimensions of the current agrarian transformations in and around BRICS, and the emerging corrupt democracies, when autocratic governments use institutionalized or other forms of violence to ensure the profit of capitalist elites. This situation is clear if we consider the complacency of the Brazilian government with the illegal mechanisms corporations use to expel rural communities from their lands, which was described by José Paulo Pietrafesa (UFG, Brazil) at this session.

After the general discussion about BRICS cooperation and state policies, the next plenary sessions focused on the most relevant issues for the BICAS initiative such as the interconnections of agricultural production, environment and food sovereignty. The third plenary session started with the presentation of Ruth Hall (PLAAS, South Africa) on the institutional changes in the agrarian reform in South Africa. These changes lead to significant transformations in the mode of food production and control of natural resources amplifying peasant protagonism in the national food security and sovereignty strategy. This situation contradicts the Russian and Brazilian cases: according to Alexander Kurakin (RANEPA, Russia), the Russian

P. Niederle

BRICS cooperation for the Critical Agrarian Studies:

Challenges for the international research network under the new global geopolitics 
170 food security strategy favors large and medium-sized farmers rather than household plots that reduce the production (for instance, of pork) due to the increasingly restrictive public norms.

НАУЧНАЯ

ЖИЗнь

Three speakers - Arilson Favareto (UFABC), Claudia Schmidt (CPDA) and Lauro Mattei (UFSC) - presented a very pessimistic picture of recent changes in the Brazilian state policies proving an abrupt shift from the developmental-democratic state of the Workers Party governments (2003-2016) to the neoliberal-authoritarian state developing from 2016, mainly after the President Bolsonaro election in 2018. All Brazilian researchers believe that this shift has amplified the power of agribusiness corporations and oligarchies, favored the expansion of the commodity frontier, and threatened the reproduction of rural peasant communities and natural and collective resources increasingly privatized by means of the counter-agrarian reform. They also highlighted the collapse of the previous compromise that supported the fragile coexistence of agribusinesses and family farms, which leads to the extinction of some public policies. Due to the fact that the latter group ensures the domestic food supply, the Brazilian food security and sovereignty is now in danger, which contradicts the global geopolitical image of the country.

The fourth plenary session discussed commodity production, land grabbing and financialization of the agrifood system. Some interesting data were presented by Sergio Leite (CPDA, Brazil), who described different mechanisms linking land and green grabbing with financial dynamics of contemporary capitalism. Leite explained how the impersonality of the financial funds hides the relationships that support their profitability. For instance, the New York University professors are not aware of the fact that some funds that control their pensions are engaged in illegal land grabbing practices in South America. However, what would they do if they knew that? Henry Bernstein (SOAS, UK) questioned the peasants' capacity to face this increasingly financialized agrarian capitalism. But if not peasants then would professors or consumers confront the financial capital?

Resistance is the core of the contemporary agrarian question and was one of the main issues of the final plenary, at which Wendy Wolford (Cornell University, US), Bernardo Fernandes (UNESP, Brazil) and Leonilde Medeiros (CPDA, Brazil) summarized the results of the conference. First, the traditional agrarian question is still relevant today but is related to new questions of natural resources control, and wider agrifood and ecological issues. Second, there is a new agenda of the control of "territories" (not only land) due to the movements of resistance that are increasingly territorialized and use complex strategies in which values and social-cultural identities are as important as economic goals.

All these issues were also discussed in the Working Groups whose proceedings are available at http://conferencias.unb.br/index.php/bicas/bicas. It is not possible to summarize all 65 papers presented, but 
I would like to identify thematic foci of all groups: 1) regional influences and development: BRICS trade and investments across the Global South; 2) South-South cooperation: policy transfer and state influences among BRICS and MICS (Middle-Income Countries); 3) new state-market relations in BRICS and MICS; 4) environmental crisis and agro-ecology in Latin America and the Global South; 5) resurgent authoritarianism and populism in the contemporary political and agrarian transitions; 6) agrarian transformations, rural and territorial development in BRICS; 7) land, environment, food sovereignty: resistance and social movements; 8) land and water grabbing. Thus, the BICAS initiative is on the frontier of the contemporary debates on the political economy of agrifood studies.

As the plenary sessions most working papers focused on the Brazilian agrarian economy for the country hosted the conference. Moreover, the BICAS discussions were very interesting for the Brazilian audience due to the abrupt political rupture after the impeachment of the President Dilma Roussef in 2016. Therefore, the conference discussed the new Brazilian context not only because it has direct implications for rural researchers and organizations in the country, but also because it can affect rural development policies in other countries: for the last two decades Brazil has been a leading actor at the international forums on agrifood management and on family farming and food security policies transfers.

At the same time all participants were concerned about the Brazilian political-economic changes associated with the global rise of conservative movements. The conference identified similarities and differences in the situation worldwide. Thus, similarities are mainly related to the rise of authoritarian populism that threatens democratic institutions; while differences are mostly economic, for example, the divergent routes of Brazil and Russia - a more subordinated path of Brazil and a more autonomous path of Russia to the global food regime. It is important to emphasize that the new Brazilian President Jair Bolsonaro (the so-called "tropical Trump") has become an element of tension inside BRICS: his minister of foreign affairs has already mentioned that the new government would be much more interested in bilateral negotiations than in multilateral governance. Besides, the realignment of the Brazilian government to the US international politics has already led to tensions with Russia and China in trade (soy export) and political filed (Venezuela crisis).

Considering this new geopolitical context, what would be the mode of the BICAS cooperation in the next years? On the one hand, the new agrarian question will probably be at the core of the global agenda of the BRICS countries acting as a coherent bloc or in the opposite way, and the BRICS countries will still focus on the intensity of changes in their agriculture and agrifood systems. On the other hand, the consolidation of autocratic and neoliberal governments can lead to serious restrictions for cooperation in critical agrarian studies and,
P. Niederle

BRICS cooperation for the Critical Agrarian Studies: Challenges for the international research network under the new global geopolitics 
172 even more, for the dialogue between scholars and social movements. In India, China, Russia and Brazil social movements and NGOs face

нАучнАЯ an increasingly restrictive context. These actors are already trying to жизнь change their strategies of action, and, perhaps, researches will also have to change traditional forms of academic cooperation.

\section{Сотрудничество стран БРИКС в области критических аграрных исследований: задачи международного сообщества ученых в новом геополитическом контексте}

Паоло Нидерле, доктор социологических наук, доцент Федерального университета Риу-Гранди-ду-Сул (Порту-Аллегри, Бразилия). E-mail: pauloniederle@gmail.com.ru 